\title{
Environmental Attitudes and Behaviors in the Philippines
}

\author{
Joseph Anthony L. Reyes \\ Graduate School of Environmental Studies, Tohoku University \\ Email: reyes@cneas.tohoku.ac.jp
}

\section{Doi:10.5901/jesr.2014.v4n6p87}

\begin{abstract}
Data from the environment modules of the International Social Survey Programme in 1993, 2000, and 2010 were analyzed to explore attitudinal dimensions, trends and significant predictors of public and private behavior in the Philippines. Factor analyses of attitude items indicate a consistent grouping of negatively connoted perceptions towards nature and science in the three datasets. A series of OLS and logistic regressions were conducted to determine significant predictors of attitudes and behaviors. Perceptions of specific environmental problems and fatalism were consistent significant predictors of negative attitudes. No significant increases were found in environmental behaviors among Filipinos over the past two decades, with Jonckheere's test indicating a significant decreasing trend. Educational attainment was the only consistently significant indicator for behaviors such as driving less, signing petitions, donating money, joining groups, and participating in public protests for the environment. These findings provide an understanding of Filipino attitudes towards science and nature, and improvements in behavior may be achieved with further integration of environmental education, and promotion to educated people to specifically engage in new forms of environmental behaviors. The implications of these results are discussed, along with opportunities for future research.
\end{abstract}

Keywords: Environmental attitudes, environmental behavior, Philippine environmentalism

\section{Introduction}

This paper examines environmental attitudes and behaviors among Filipinos utilizing International Social Survey Programme (ISSP) data on the Philippines within the last two decades. The paper begins with the discussion of the background and context of Philippine environmentalism drawn from previous literature, followed by the objectives of the study. It then presents results of factor analysis on public attitudes pertaining to science and nature and its consistent dimension. The Negativity factor is then examined through a series of Ordinary Least-Squares regressions with other substantive survey and demographic control variables. Logistic regression is then performed to investigate significant predictors on the prevalence of public and private environmental behaviors. The last section discusses the implications of the findings and conclusions of the study.

\subsection{Background}

The Philippines is an archipelagic country located in Southeast Asia, with over 7,000 islands, and a total area of about $300,000 \mathrm{~km}^{2}$. Geography, terrain, and climate determine human settlement patterns, socioeconomic opportunities and constraints, and their intricate relationship with environment and natural resources (ENR) conditions (ADB, 2009, p.3). The country is considered as a developing nation, mainly rural engaging in agriculture activity with pockets of massive urbanization (Kong, Poh Ai, Gusti Tisna, Remorin, Suwannatachote, \& Lee, 2000, p. 114). Filipinos traditionally come from agrarian societies and can be categorized into three groups in terms of religion: Christian lowlanders that make up $90 \%$ of the population, Muslims making up 5\% reside mostly in the southern area of Mindanao, while the rest can be considered as native animists dispersed all throughout the countryside. Similar to other countries in Southeast Asia, a degree of animism also infuses the practices of world religions in the Philippines. As such, the Philippines may still be perceived a predominantly rural society with values rooted in a long history of peasantry that should be considered in understanding its traditional values (Kong et al., 2000, p. 123).

Being situated along the "Typhoon Belt" in the Pacific and the "Pacific Ring of Fire", The Philippines is vulnerable to natural disasters, primarily typhoons, floods, earthquakes, and volcanic eruptions. About 20-30 typhoons hit the country annually between June and November such as the devastating tropical storm Ondoy (Ketsana) in 2009 and tropical cyclone Yolanda (Haian) in 2013. In addition, 22 volcanoes are active in the country, and several destructive 
eruptions and earthquakes have occurred in recent years (ADB, 2009, p.3). These natural calamities damage crops and properties, displace people, and claim thousands of lives.

Conditions such as these can contribute to essentially two sets of problems recurring in South East Asian countries, confronted by those in rural and urban areas: The inability of the agricultural sector to provide sufficiently for the livelihood of the rural dwellers; while at the same time, vulnerability and displacement due to natural disasters in rural areas and the increasing rate of land conversion from agricultural to industrial leading to a rapid increase in rural-urban migration. Such unplanned urban explosion place tremendous stress on the environment, manifesting as extreme congestion, air, water, and land pollution, and sewage and rubbish disposal problems (Kong et al., 2000, p. 117). One such example is the Payatas Dumpsite in Manila, with garbage accumulating rapidly as the city generates daily 'about 4000 metric tons of solid waste, where only a portion collected with the rest dumped into waterways or burned, creating health and aesthetic problems' (Kong et al., 2000, p. 114) and had also claimed the lives of hundreds in a landslide of junk in July 2000. As for the countryside, problems include: Degradation of forestland, loss of watershed integrity, inappropriate and unsustainable land use and agricultural practices in upland areas, degradation of near shore coastal areas due to sedimentation from upstream sources, overexploitation of fisheries and permanent loss of coastal ecosystems from changes in land use due to urbanization and industrialization (ADB, 2009, p. xiv-xv). Moreover, structural causes of vulnerability found in the Philippines' historico-cultural heritage, political-economy, and difficult access to resources connect with each other and interact as a system, resulting in interconnected situations of insecurity. It is difficult to dissociate present-day political economy context and the access to resources from their historical heritage. Whereas limited access to resources constrain economic development and further widens the gap between social classes induced by the political system (Gaillard et al., 2005, pp. 59-61).

Thus, a sense of human powerlessness and fatalism in the face of the divinely inspired wrath of nature can be found in Philippine society (Bankoff, 2004, p.95). Filipinos display a range of traditional and cultural coping mechanisms, principal among these practices are often conveyed in the expression "bahala na". However, beyond the literal translation of "leave it to fate", this phrase indicates a form of reasoning where behavior is determined in terms of the discourse of science and the calculation of probabilities and also provides "a formidable armor against the suffering brought by disasters rather than a simple fatalistic attitude" (Bankoff, 2004, pp.103-104).

\subsection{Environmentalism in the Philippines}

The history of contemporary environmentalism in the Philippines can be characterized as a struggle for equity, its advocates linking the fight for environmental protection with the effort to democratize access to natural resources (Magno, 1993, p.7). Herein, small local communities attempt to recover the environment from gigantic private commercial interests, emphasizing the role of indigenous and community-based models of resource management to pursue a new development agenda (p.8).

It was in the adverse conditions of martial law during the 1970s and 1980s that the proliferation of NonGovernmental Organizations (NGOs) transpired, in a political context of authoritarian rule, with government operating as the machinery controlling or oppressing the population and enriching power holders, rather than an institution encouraging political participation and delivering basic services. NGOs became alternative avenues for engaging in participatory processes and for implementing livelihood projects. Environmental groups and coalitions were organized to protest state-sponsored, foreign-funded, and pollution-causing development projects such as the Bataan Nuclear Power Plant, the Kawasaki Sintering Plant in Cagayan De Oro, and the Copper Smelter Plant in Batangas (p. 12).

The sentiment of the time were aptly expressed in the First Philippine Environmental Congress in 1979, with the attempts towards coordination of environmental organizations, leading to the passage of a "Declaration of Environmental Concern" stating that "at the root of environmental problems are social, economic, and political systems imposed upon this nation which allowed greed and exploitation to predominate over a proper respect for the well-being of present and future generations" (p.13).

The political landscape of the Philippines had changed drastically and become more vibrant since then, by the year 2000 there were over 45,000 registered NGOs with just as many people's organizations (Kong et al., 2000, p. 131). However, many environmental NGOs still remain true to their grass-root approaches even after the 1986 EDSA People Power Revolution, offering support to tribal groups in their effort to maintain the integrity of their ecosystem, and lobbying for the adoption by the state of indigenous resource-use practices (Magno, 1993, p. 11).

Besides the NGOs, other sectors have participated in environmentalism. Large corporations in the Philippines whether by law or voluntarily, had started developing innovative technologies and techniques to manage the waste they 
produce (Kong et al., 2000, p. 131). The environmental movement was also supported by the church and community action. During the 1990s, in place of human rights activism, the new environmental activism by the church had attracted dangers to its practitioners in the field because of the threat they pose to established interests (Magno, 1993, p. 15). Those involved with church movements perceived ecological destruction as an attack on the natural world benefiting only a few, and rapidly wilting away at the very base of the living world and endangering its fruitfulness for future generations (p. 14). Basic Christian communities (BCCs) emphasized collective reflections on the sources of social deprivation, considering the effects of environmental destruction on their means of livelihood. Within such configurations of environmental advocacy, local communities had decided to fight for the forests because it meant saving their lives (Magno, 1993, p.16).

In its attempts to address these environmental concerns, the Philippine government had committed itself to environmental protection and natural resource management expressed through a comprehensive legal and regulatory regime. ENR management is mandated by the Philippine Environmental Policy and the Philippine Environment Code (Presidential Decree No. 1151, 1152, s. 1977), the Philippine Strategy for Sustainable Development of 1989, Executive Order No. 15 in 1992 that created the Philippine Council for Sustainable Development (PCSD) and the National Action Plan for Sustainable Development of 1996. The Local Government Code of 1991 also contains provisions related to devolution and implementation of ENR laws and regulations. Major ENR laws signed in the past 7 years include the Ecological Solid Waste Management Act of 2000, the Wildlife Resources Conservation and Protection Act of 2001, the Public Land Act of 2002, the Philippine Clean Water Act of 2004, and the Bio-fuels Act of 2006. Priorities of the Department of Environment and Natural Resources (DENR) relate to major government planning frameworks including the country's Medium-Term Philippine Development Plan and the Millennium Development Goals (ADB, 2009, p. xv). Of particular relevance for this study is the institutionalization of the Philippine Economic Environmental and Natural Resources Accounting (PEENRA) System in 1997, pursuant to Executive Order No. 406, allowing the creation of units within the organizational structure of three relevant governmental organizations, that are tasked to generate macroindicators that reflect the relationships and interactions between economy and the natural resources, and the establishment of a reliable data base on social valuation estimates of environmental services ( $p . x v i)$.

The Philippines recognizing the importance of international cooperation in achieving its national development goals, had signed international and regional agreements on biodiversity, hazardous chemicals and wastes, ozonedepleting substances, persistent organic pollutants, and climate change (p. xvi). However, even with international arrangements and assistance, challenges persist. Despite the existence of the Philippine Council for Sustainable Development, the first body in Asia to be established following the Rio Earth Summit's proposal to set up a Commission on Sustainable Development, and institutional acceptance of ecological security, as embodied in the Convention on International Trade for Endangered Species (CITES), taking precedence over trade agreements in the General Agreement on Tariff and Trade (GATT), significant environmental problems still remain (Kong et al., 2000, p. 129).

\subsection{Environmental education}

Similar to other Southeast Asian countries, environmental education in the Philippines has been incorporated into curriculum as part of other subjects such as science, social studies, geography, civics, and moral education, rather than a distinctly separate subject. There is also a pronounced environmental educational plan in the Philippines. Initiated in 1989, a National Strategy on Environmental Education (NSEE) aims to develop an environmentally literate and responsible citizenry that would ensure the protection and improvement of the country's environment in order to promote and implement sustainability, social equity, and economic efficiency in the use of its natural resources (Kong et al., 2000, p. 129). The mandates for sustainable development in education were strengthened with the release of the National Environmental Education Action Plan for Sustainable Development for 2005 to 2014, specifically prepared to coincide with the UN Decade of Education for Sustainable Development (Didham \& Ofei-Manu, 2012).

In addition to state-led efforts, two national networks for environmental education: the Environmental Education Network of the Philippines, Inc. (EENP) and the Philippine Association of Tertiary Level Educational Institutions in Environmental Protection and Management (PATLEPAM), advocates for the integration of sustainable development in school curricula as well as in campus administration and organizational culture. Significant developments in environmental education for sustainable development (EESD) include the creation of undergraduate and graduate degree programs with an environmental focus that are now offered by many academic institutions, and training programs offered by both government agencies and individual institutions. For instance, the Dark Green School program of the EENP has the objective of producing citizens through college systems, who are coherently directed towards EESD and 
offer a distinctive "whole institution" approach and accreditation system devised in line with the principles of EESD for coherent systemic change and accelerate the "greening" of the academy (Galang, 2010, pp. 174-176).

With the historical and contextual background of Philippine environmentalism in mind, this paper now turns toward understanding the Filipino public, to explore how attitudinal and other substantial variables at the individual level can be interpreted and related to environmentally significant behaviors.

\subsection{Environmental Attitudes}

By the 1970s, people in many parts of the world had already started questioning the basic beliefs in the Dominant Social Paradigm (DSP) that espoused progress, technology, materialism, development and separation of humans from nature (Pirages \& Ehrlich, 1974, pp. 44-47). In contrast to this, Dunlap and Van Liere's (1978) New Environmental Paradigm highlighted themes concerning the existence of ecological limits to growth, maintaining the delicate balance of nature, and the rejection of anthropocentric views towards nature's being primarily for human use. Moreover, the NEP took account of the wider view of the relationship between modern societies and the environment with its scale acting as a measure of proposed shift in people's worldviews (Van Petegem \& Blieck, 2006, p.625). Early environmental discourse and interpretations of socio-environmental system interactions had been influenced by the dichotomy.

Previous literature that utilized ISSP surveys such as Aoyagi-Usui (1999, p.125) and Reyes (2013) classified corresponding questions on "attitudes towards science and nature" as expressing either Dominant Social Paradigm (DSP) or New Environmental Paradigm (NEP) ideas (refer to appendix). Among the fourteen questions utilized in prior research, eight were available in the ISSP 1993, 2000, and 2010 modules, while six were found in the analysis to be grouped consistently, which were then subsequently utilized in this paper to represent the public environmental attitudes of Filipinos. Other studies had also analyzed these attitudinal items using factor analyses (Aoyagi-Usui, Vinken, \& Kuribayashi, 2003; Corral-Verdugo, Carrus, Bonnes, Moser, \& Sinha, 2008; Van Petegem \& Blieck, 2006) to find underlying dimensions, these are also often combined with willingness and efficacy variables and considered as "Environmental concern". Franzen and Meyer (2010) operationalized concern with other substantial variables such as postmaterialism, specific dangers, environmental knowledge and demographics as predictors. Environmental Concern is similarly used by Carriere \& Scruggs (2001) in their study empirically relating attitudes to egalitarian, individualist, hierarchist, and fatalistic cultural biases. Moreover, Guagnano, Stern, and Dietz (1995) had proposed an AttitudeBehavior-Context interactive model that found relationships between external and internal influences on behavior change in curbside recycling.

\subsection{Environmentally significant Behavior}

In the three ISSP surveys, there were six recurring items for respondents' self-reported behaviors: Sorting recyclables, driving automobiles less for the environment, signing petitions, donating money, membership to environmental groups, and participation in public protest demonstrations within the last five years. Studying these variables provides a better understanding of who does and who does not engage in environmentally-oriented behaviors within particular national contexts (Hunter, Hatch, \& Johnson, 2004, p. 681). Several multinational and focused studies (Hadler \& Haller 2011, 2013; Kelly, Kennedy, Faughnan, \& Tovey, 2003) had classified the first two as belonging to private sphere behaviors, while the remaining four as part of the public sphere, covering both activism and non-activists' behavior. Previous research had also found gender distinctions with regard to some environmental behaviors within most of a cross-national analysis of 22 countries, particularly gender differences in the level of private environmental behaviors seemingly more consistent within nations at the upper end of the wealth distribution (Hunter et al., 2004).

Aside from analyzing indicators of the different types of individual environmental behavior, the distinction between public and private, allows a general understanding of trends that may be of significance to environmentalism. Overall, Hadler and Haller (2013) had observed three trends that have occurred across 16 countries that participated in the ISSP: First, a homogenization in both public and private behaviors; Second, increasing prosperity, increasing international ties, and better political opportunity structures can have negative effects to behaviors; and third, the growing gap between the two behaviors seem to indicate a shift from public to private environmental behaviors. Other researchers (such as Aoyagi-Usui, et al., 2003; Corral-Verdugo, et al., 2008) using varied datasets had also found significant relationships between behavior with latent dimensions of environmental attitudes and values, together discovering similar patterns among certain countries.

Interestingly, though existing literature had measured and determined significant predictors of environmental 
attitudes and behavior in many countries and contexts, very few had found significant indicators for Philippine samples that would be similar to those present in samples from developed nations, or even consistent factors when sampling different parts of the country. At the time of this writing, there have been very few environmental surveys in the Philippines that had a comparable number of respondents, coverage, and extent of surveying as the ISSP, the World Values Survey, for instance, contained Philippine data for 1995 and 2000, but only had a handful of variables measuring environmental perspectives and behavioral intentions. Moreover, no study has ever conducted detailed empirical analysis of ISSP data for environmental attitudes and behavior specifically for the Philippines, despite the fact that it has been part of the ISSP surveys for over 20 years and the only Asian developing country that participated for all three environmental surveys. Hence, this study may provide potential academic and applied contributions that have yet to be explored.

\section{Objectives of the Study}

This paper investigates environmental attitudes and behavior in the Philippines. At the outset, given the limitation of substantial variables that are consistently available for three ISSP surveys, it will determine recurring environmental attitude dimensions, and subsequently relate these to other significant determinants of private and public behavior. The analysis specifically addresses the following research questions:

1. How has the prevalence environmental behavior among Filipinos changed over the past two decades?

2. What are the structures of environmental attitudes in the Philippines?

2a. What is the relationship between environmental attitudes and other values?

2b. What are the factors contributing to environmental behavior among Filipinos?

Finally, the study also aims towards an understanding of attitudinal and behavioral changes across time, education, and future implications.

\section{Data}

Analyses are based on data from the International Social Survey Programme (ISSP) from the years 1993, 2000, and 2010. The ISSP is a continuing annual program of cross-national collaboration on surveys of currently 48 member countries, covering topics important for social science research and developing annual surveys focused on a single topic (see www.issp.org). The ISSP employs a questionnaire method on highly representative national random samples. The standard sampling procedure is a stratified, multistage random sample considering region, household and persons within the household. The three ISSP environment modules measure attitudes to environmental protection and preferred governmental approaches.

The target populations for the Philippine subsamples were adults, with ages ranging from 18 to 91 years old. The sample size in each of the three surveys used is 1200 with equal number of female and male respondents. ISSP datasets, questionnaires, and relevant material are provided by the Zentralarchiv für Empirische Sozialforschung, University of Cologne and can be found at the GESIS Data Archive (http://zacat.gesis.org/). Surveys in the Philippines were done by the Social Weather Stations (SWS), a private and independent academic institute that conduct survey research on topics of public interest for governmental, public and private organizations. Its national surveys are conducted in Tagalog, llocano, Bikol, Cebuano, and llonggo; with every questionnaire bilingual using English as the second language. For the ISSP environment surveys, fieldwork was conducted in 1993,2000, and 2009/2010, the first two surveys in 1993 and 2000 had Tagalog questionnaires, while the 2010 survey also had Bicolano, Cebuano, Hiligaynon, lluko, Maranao, and Waray versions (http://www.gesis.org/en/issp/issp-modules-profiles/environment/). Original data from the Philippine data are archived in the SWS Survey Data Bank that contains time series data on general social and political concerns in the country.

Among the three Philippine subsamples from the ISSP surveys, relatively consistent topics covered were: 1) "Attitudes towards science and nature", 2) "Dangers of Specific Environmental Problems", 3) "Respondent's Behavior and Environmental Protection", 4) "Environmental Efficacy", 5) "Environmental Policy and Locus of Control", 6) "Left-right Dimension", and 7) Demographics. The item on postmaterialism was modified while questions for "Scientific and Environmental Knowledge" also became optional in the 2010 survey; variables within the above-mentioned topics present in all three modules and available in the Philippine surveys are primarily utilized in the analyses. Additional descriptive information on the surveys and variables used in this study can be found in the appendix. 


\section{Investigation Results and Analysis}

\subsection{Prevalence of private and public environmental behaviors among Filipinos}

For the private behaviors of sorting recyclables and driving less for the environment, Kruskal-Wallis tests revealed statistically significant differences $(H(2)=308.205, p<.001)$ existing between frequencies of engagement among the three Philippine survey years. Jonckheere's test indicated a significant decreasing trend in the data, $\mathrm{J}=1392197.00, \mathrm{z}=$ 17.526, $r=.301$ (Field, 2009, pp. 569-571). Similarly for public behaviors of signing petitions, donating money, joining environmental groups and participating in protests, there were statistically significant differences $(H(2)=41.595, p<.001)$ existing between frequencies of engagement among the three Philippine survey years and also indicated a significant decreasing trend in the data, $\mathrm{J}=2074363.000, z=-3.666, r=.061$.

Table 1 shows the results of logistic regression analysis (Field, 2009, pp. 264-294) using year as indicator variable for specific environmental behaviors. Based on available data, there were no significant increases when comparing 1993 to 2010. Moreover, significant decreases for both donating money and participation in public protests for the environment was found when comparing responses in 1993 to 2000, and comparing 2000 to 2010. In summary, only significant decreases were found in the frequency and prevalence of environmental behaviors among Filipinos.

Table 1: Magnitude and homogeneity of public and private behavior over time, and logistic regression analysis using year as predictor variable

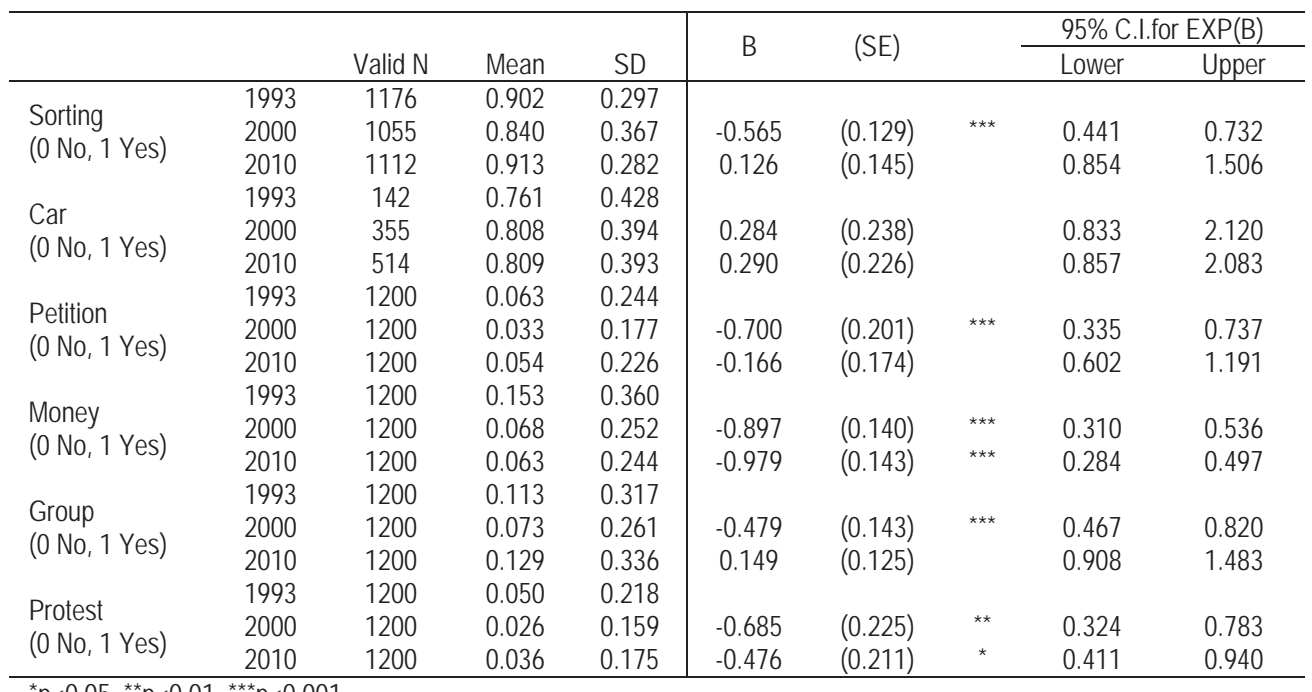

${ }^{*} \mathrm{p}<0.05,{ }^{* \star} \mathrm{p}<0.01,{ }^{* \star *} \mathrm{p}<0.001$

Figures in B column are Logistic regression Beta coefficients using survey year as indicator and figures in parenthesis are Standard Errors

Though there were no significant increases found in both private and public environmental behaviors, it is also worth mentioning that the Philippines has somewhat maintained its rank in relation with the other 15 countries that participated in the ISSP for the 1993, 2000, and 2010 surveys occupying the upper middle ranks for private behavior while the lower middle ranks for public behavior. It also appears to share more similarity in the patterns of changes over time with developing and post-communist countries such as Bulgaria and Russia as opposed to the more industrialized nations (Hadler \& Haller, 2013, pp. 486-487).

\subsection{Environmental attitudes in the Philippines}

In examining the relationship between attitudes and behavior in the Philippines, this study adopts similar methods utilized by previous research on environmental attitudes, values, concerns and behavior (Aoyagi-Usui, 1999; Aoyagi-Usui et. al., 2003; Franzen \& Meyer, 2010; Guagnano et al., 1995; Kelly et al., 2003; Motherway, Kelly, Faughnan, \& Tovey, 2003; 
Reyes, 2013; Van Petegem \& Blieck, 2006). It employs explorative factor analysis via the principal component method on three ISSP datasets using the Philippine samples and focusing on consistent variables of "attitudes towards science and nature", other "substantive variables", and demographic data of the respondents. Following a similar approach to AoyagiUsui et al. (2003), it first determines the underlying attitudinal dimension within each of the 1993, 2000, and 2010 datasets, then explores their relationship to other variables such as general values and demographics. These are then all used in logistic regression models to predict the prevalence of different forms of environmental behavior.

Previous research on ISSP environmental attitudes had indicated that certain post-communist and developing countries did not exhibit bi-dimensional patterns similar to developed countries (Reyes 2013). Moreover, initial factor analyses and forced factor solutions on the three datasets for the Philippines did not yield items that all met an acceptable level of reliability of Cronbach's alpha of 0.6 or higher (Robinson, Shaver, \& Wrightsman, 1991). Reliability analyses of the eight attitudinal variables as a single scale for each dataset indicated increased alpha with the deletion of two items ("In order to protect the environment, the Philippines needs economic growth" and "Modern science will solve our environmental problems with little change to our way of life"). The remaining six variables were composed of statements towards science and nature with negative connotations (Negativity), as opposed to the two removed variables which had relatively positive connotation. Subsequent factor analyses on the six variables all produced single-factor solutions for 1993, 2000, and 2010. Interestingly, as Hayes \& Tariq (2000) also points out, the negative wording of statements such as these which are used to gauge public attitude toward organized science and its influence on the natural world avoids acquiescence response bias, or the tendency of respondents simply to agree with whatever the interviewer says (p.438).

As the six statements express both technocentric and pessimistic perspectives (Aoyagi-Usui, 1999; Reyes, 2013), such grouping could also be interpreted as an example of the blurred lines between worldviews in less industrialized countries, as compared to developed countries with its clear-cut distinction between anthropocentric and ecological perspectives (Van Petegem \& Blieck, 2006, pp. 632-633). Previous studies have also implied that this can be considered a holistic view wherein people can show concern with the negative human impact on ecological systems and, at the same time, believe in limited human usage of nature, which can be attributed to their nature-extractive tradition (pp. 631633). The attitudinal amalgamations of seemingly opposing worldviews can also be found elsewhere in the developing world as previous research in Zimbabwe and Mexico had shown (Corral-Verdugo, et al., 2008; Van Petegem \& Blieck, 2006). Such findings of the 'dynamic combination and integration of anthropocentrism with ecocentrism is touted as even being superior to the sole endorsement of an ecocentric worldview in guiding conservation behavior, particularly when these anthropocentric views are able to determine the necessity of human planned and regulated ways for more sustainable use of natural resources' avoiding the dichotomous conflict with the idea of environmental conservation'(Corral-Verdugo et al., 2008, pp. 720-721).

Table 2 shows the items associated in the derived Negativity scale, together with their factor loadings, eigenvalues, variances explained, and Cronbach's alpha coefficients. This study followed the criteria that most studies and statistical software packages use in exploratory factor analysis: Using the Kaiser-Meyer-Olkin measurement above .60 and significance of Bartlett's test of spherecity for the suitability of the datasets; While the "Kaiser criterion" or "K1 rule" of eigenvalues greater than one and the "Scree test" where eigenvalues are plotted against the number of components and as the plot moves towards later components there is a sharp decrease in eigenvalues which then levels off in order to determine the number of principal components to retain(Tabachnick \& Fidell, 2006, pp. 607-675). The single factor obtained from each dataset satisfied the conditions and had eigenvalues greater than 1 and accounted for over $35 \%$ of the variance. The factor loadings of all variables were also adequate having values over .45 levels (Comrey \& Lee, 1992). Using a subscale of the Negativity variables, univariate analysis and bivariate linear regression found survey year to be significant $(b=0.016, t=10.91, p<.001)$, indicating a slight increase of agreement to negatively connoted attitudes towards science and nature among Filipinos from 1993 to 2010. 
Table 2: Attitudes towards science and nature in the Philippines

\begin{tabular}{|c|c|c|c|}
\hline & $\begin{array}{c}1993 \\
\text { Factor } 1\end{array}$ & $\begin{array}{c}2000 \\
\text { Factor } 1\end{array}$ & $\begin{array}{c}2010 \\
\text { Factor } 1\end{array}$ \\
\hline a. Almost everything we do in modern life harms the environment & 0.635 & 0.690 & 0.704 \\
\hline b. Economic growth always harms the environment & 0.611 & 0.628 & 0.635 \\
\hline c. Overall, modern science does more harm than good & 0.626 & 0.558 & 0.594 \\
\hline d. People worry too much about human progress harming the environment & 0.581 & 0.665 & 0.651 \\
\hline e. We worry too much about the future of the environment and not enough about prices and jobs today & 0.556 & 0.505 & 0.568 \\
\hline f. We believe too often in science, and not enough in feelings and faith & 0.567 & 0.494 & 0.467 \\
\hline Eigenvalue & 2.137 & 2.123 & 2.215 \\
\hline Total variance explained & $36 \%$ & $35 \%$ & $37 \%$ \\
\hline Cronbach's Alpha & 0.637 & 0.628 & 0.655 \\
\hline
\end{tabular}

\subsection{Relationship between attitudes and other substantial variables}

After conducting additional factor analyses and tests of reliability on the other substantial ISSP variables of the three datasets, two factors were found to have consistent item groupings: a factor comprised of items that indicate the respondent's willingness to make trade-offs with the environment (Willingness); and another factor that is comprised of items that assess specific environmental risks (Dangers). Table 3 shows the factor loadings in each of the two for 1993, 2000, and 2010, eigenvalues, and variances explained. However, the other derived factors for the remaining substantial variables had relatively low levels of reliability for their groupings, not obtaining Cronbach's alpha of 0.6 or higher. Hence, employing similar procedures in Aoyagi et al. (2003, pp. 28-29) the factor scores of Negativity, Willingness, and Dangers, are used for the analysis while at the same time demographics and other remaining substantial variables are used in their respective individual scales.

Table 3: Results of factor analysis on other substantive variables

\begin{tabular}{|c|c|c|c|c|c|}
\hline 1993 Item & Loading & 2000 Item & Loading & 2010 Item & Loading \\
\hline $\begin{array}{l}\text { Factor } 1 \text { - Willingness } \\
\text { to make Trade-offs with } \\
\text { the environment }\end{array}$ & & $\begin{array}{l}\text { Factor } 1 \text { - Dangers of } \\
\text { Specific } \\
\text { Environmental } \\
\text { Problems }\end{array}$ & & $\begin{array}{l}\text { Factor } 1 \text { - Dangers of } \\
\text { Specific Environmental } \\
\text { Problems }\end{array}$ & \\
\hline Taxes & 0.854 & AirPollndEnv & 0.756 & AirPollndEnv & 0.739 \\
\hline Prices & 0.803 & RiseWorldTemp & 0.744 & AirPolCarEnv & 0.735 \\
\hline \multirow[t]{3}{*}{ Living } & 0.772 & PolLakeRivEnv & 0.741 & RiseWorldTemp & 0.693 \\
\hline & & PestFarmEnv & 0.729 & PolLakeRivEnv & 0.680 \\
\hline & & AirPolCarEnv & 0.678 & PestFarmEnv & 0.653 \\
\hline Eigenvalue & 1.976 & Eigenvalue & 2.677 & Eigenvalue & 2.459 \\
\hline $\begin{array}{l}\text { Factor } 2 \text { - Dangers of } \\
\text { Specific Environmental } \\
\text { Problems }\end{array}$ & & $\begin{array}{l}\text { Factor } 2 \text {-Willingness } \\
\text { to make Trade-offs } \\
\text { with the environment }\end{array}$ & & $\begin{array}{l}\text { Factor } 2 \text { - Willingness to } \\
\text { make Trade-offs with the } \\
\text { environment }\end{array}$ & \\
\hline PolLakeRivEnv & 0.661 & Taxes & & Taxes & \\
\hline AirPollndEnv & 0.651 & Prices & 0.870 & Prices & 0.882 \\
\hline RiseWorldTemp & 0.612 & Living & 0.858 & Living & 0.854 \\
\hline PestFarmEnv & 0.604 & & 0.756 & & 0.741 \\
\hline AirPolCarEnv & 0.555 & & & & \\
\hline Eigenvalue & 1.907 & Eigenvalue & 2.066 & Eigenvalue & 2.061 \\
\hline Total variance explained & $49 \%$ & $\begin{array}{l}\text { Total variance } \\
\text { explained }\end{array}$ & $59 \%$ & Total variance explained & $56 \%$ \\
\hline
\end{tabular}

To initially determine the retention of variables for regression, several automated statistical procedures are available that allow forward, backward, and stepwise selection of variables, with several user-modifiable statistical criteria for variable selection (Tabachnick \& Fidell, 2006, p.188). The backward method is employed in this study to remove individual variables according to the criteria set for removal until a model is reached where no more variables are eligible for removal, this is done by placing all predictors in the model and then calculating the contribution of each one by looking at 
the significance value of the t-test for each predictor and then comparing against the removal criterion (Field, 2009, p.213) - initially specified as the probability of $F>=.1$ to remove an independent variable from the equation, this is done along with a comparison of the adjusted $\mathrm{R}^{2}$ of the model with the variable included against the adjusted $\mathrm{R}^{2}$ of the model with the variable excluded (p. 221). Additionally, an important consideration in deciding predictors to be included was the theoretical literature available, the initial model was based upon previous research including meaningful variables in the model in their order of importance with the regression repeated with the exclusion of variables (pp.213-214) that were found to be statistically redundant for all three datasets.

Willingness and Dangers were the only predictors of Negativity attitudes initially found to be consistently significant in all three datasets, along with these other significant predictors considered for the analysis were: The respondent's selfefficacy items stating difficulty of helping the environment (EfficFatalism) and doing what is right even at the cost of money and time (EfficAltruism); Locus of control for environmental protection(State intervention); and Postmaterialism. These substantial variables are then combined with demographic control variables frequently utilized in myriad studies utilizing ISSP surveys such as: Age, gender, urban or rural settings, education, marital status (Hadler \& Haller, 2011; Hayes \& Tariq, 2000; Franzen \& Vogl, 2013; Marquart-Pyatt, 2012), along with self-assessed subjective socio-economic class within the Philippines (Sabio 2012) in an ordinary least-squares regression similar to the approach of Aoyagi-Usui et al. (2003) in order to explore the relationship to environmental attitudes (Table 4). The final model found Dangers and EfficFatalism to be significant in all datasets. Age, marital status, and self-perceived socio-economic status were not found to be significant, while gender and education was found only significant in 1993 and 2010 respectively. These results in the Philippines offer a contrast to those in Anglo-American countries that found both gender and education to be consistent predictors of attitudes (Hayes \& Tariq, 2000, p.440-442).

Table 4: Results of regressions for environmental attitudes of the three ISSP Philippine samples

\begin{tabular}{|c|c|c|c|c|c|c|c|c|c|}
\hline & 1993 & & & 2000 & & & 2010 & & \\
\hline Willingness (Factor scores) & 0.134 & $(0.030)$ & 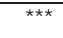 & 0.072 & $(0.032)$ & * & 0.023 & $(0.033)$ & \\
\hline Dangers (Factor scores) & 0.142 & $(0.029)$ & $\star \star \star$ & 0.128 & $(0.032)$ & *** & 0.125 & $(0.034)$ & $\star \star \star$ \\
\hline Fatalism (Lo 1 to Hi 5) & 0.170 & $(0.031)$ & $* \star *$ & 0.109 & $(0.030)$ & 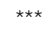 & 0.139 & $(0.026)$ & $\star \star *$ \\
\hline Altruism (Lo 1 to Hi 5) & 0.127 & $(0.035)$ & 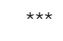 & 0.025 & $(0.033)$ & & 0.074 & $(0.030)$ & * \\
\hline Pro state intervention (Lo 1, 1.5, $\mathrm{Hi} 2$ ) & -0.107 & $(0.082)$ & & -0.195 & $(0.087)$ & * & -0.099 & $(0.101)$ & \\
\hline Postmaterialism (1 Mat to 4 PM) & 0.051 & $(0.032)$ & & 0.007 & $(0.033)$ & & -0.004 & $(0.034)$ & \\
\hline Age (Standardized) & -0.020 & $(0.032)$ & & 0.002 & $(0.036)$ & & -0.052 & $(0.036)$ & \\
\hline Gender (Female $=1$ ) & 0.113 & $(0.057)$ & * & 0.036 & $(0.063)$ & & -0.107 & $(0.064)$ & \\
\hline $\begin{array}{l}\text { Educational Level (1 Pre-secondary, } \\
2 \text { Secondary } 3 \text { Post-secondary) }\end{array}$ & 0.017 & $(0.044)$ & & -0.018 & $(0.047)$ & & 0.114 & $(0.048)$ & * \\
\hline Urban or Rural (1 or 2) & -0.134 & $(0.066)$ & * & 0.089 & $(0.067)$ & & 0.030 & $(0.067)$ & \\
\hline Living as Married ( $0 \mathrm{No}, 1 \mathrm{Yes})$ & 0.054 & $(0.067)$ & & 0.130 & $(0.075)$ & & -0.054 & $(0.070)$ & \\
\hline SWS Socio-Economic Class & 0.000 & $(0.050)$ & & -0.017 & $(0.025)$ & & 0.032 & $(0.037)$ & \\
\hline $\begin{array}{l}\text { (Constant) } \\
\mathrm{N}\end{array}$ & $\begin{array}{c}-0.789 \\
1135\end{array}$ & $(0.303)$ & ** & $\begin{array}{c}-0.211 \\
971\end{array}$ & $(0.272)$ & & $\begin{array}{c}-0.810 \\
903\end{array}$ & $(0.290)$ & ** \\
\hline R square (adj.) & & 0.094 & $\star \star \star *$ & & 0.041 & $\star \star \star *$ & & 0.067 & $\star * \star$ \\
\hline
\end{tabular}

\subsection{Indicators of Public and Private Behaviors among Filipinos}

In order to correlate environmental behaviors, logistic regressions were conducted utilizing obtained factor scores and subscales of attitudes, control demographics, and other substantial variables employing similar methodological approaches in previous literature (Aoyagi et al., 2003; Carriere \& Scruggs, 2001; Rauwald \& Moore 2002). Results of the estimation of significant variables for private and public environmental behavior in the Philippines for the 1993, 2000, and 2010 are shown in Table 5.

Overall, willingness to make sacrifices for the environment show consistent positive patterns in five of the six behaviors. Altruism had positive relationships in respondent's donating money, sorting recyclables, and group membership to environmental causes. Propensity towards state intervention was found significant only in private behaviors, having a positive relationship with sorting and a negative relationship with driving less for the environment. Fatalism, postmaterialism, and perceptions to specific environmental risks were no longer significant in most of the 
behaviors after controlling for other variables and demographics. Negative connotations on attitudes towards science and nature was found to be positive significant to joining protests, while negative significant to membership in groups.

Table 5: Results summary of substantial and demographic variables from logistic regression of environmental behaviors

\begin{tabular}{|c|c|c|c|c|c|c|c|c|c|c|c|c|c|c|c|c|c|c|}
\hline & & \multicolumn{5}{|c|}{ Private } & \multicolumn{12}{|c|}{ Public } \\
\hline & \multicolumn{3}{|c|}{ Sorting } & \multicolumn{3}{|c|}{ Car } & \multicolumn{3}{|c|}{ Petition } & \multicolumn{3}{|c|}{ Money } & \multicolumn{3}{|c|}{ Group } & \multicolumn{3}{|c|}{ Protest } \\
\hline & ঙ্গে & ষి & 옹 & ஜூ & ষ্ণ & 옹 & ঙ্গে & రి & 웅 & ஜ্ন & ষి & 웅 & ঙ্গে & ষ্ণ & 웅 & ஜ্নে & ষ্ণ & 옹 \\
\hline Willingness & & + & + & & + & + & & & & & + & & & & + & & & + \\
\hline Dangers & + & & & & & & & & & & & & & & & & & \\
\hline Fatalism & & & & + & & & & & & - & & & & & & & & \\
\hline Altruism & & & + & & & & & & & & & + & & + & & & & \\
\hline Pro state intervention & + & & & & - & & & & & & & & & & & & & \\
\hline Post materialism & & & & & & & & & & & & + & & & & & & \\
\hline Age & & & & & & & & & & & & & & & & & & \\
\hline Gender (Female $=1$ ) & + & & & & & & & & & & & & & & & & & \\
\hline Educational Level & & & & + & & + & & + & + & + & + & + & + & + & & & + & + \\
\hline Urban or Rural & & & & & + & & & & & & & & & & + & & & \\
\hline Living as Married & & & & & & + & & & & & & & & & & & & \\
\hline SWS Socio-Economic Class & & & & & & & - & & & & & - & & + & & & & \\
\hline Negativity & & & & & & & & & & & & & & - & & + & & \\
\hline
\end{tabular}

As for demographic variables, educational level of the respondents was the most consistent variable in the models and having high positive significant relationships to driving less and all public environmental behaviors. Interestingly, it was only in sorting recyclables that education was not found to be significant, which may be assumed as encountering similar patterns of mixed positive and negative correlations of solid waste management and educational attainment found in the focused studies of Del Mundo, Rebancos, and Alaira (2009, pp. 35-36) in separate Barangay locations in Batangas.

Other demographic variables that were usually found as significant predictors of behavior in other countries (Hadler \& Haller, 2011; Marquart-Pyatt, 2012) were not applicable for the Philippine samples, as age was not found to be significant for any behavior in any of the datasets, while marital status and gender being female was only found significant to driving less and sorting respectively. This highlights the need to investigate the significance of education being the most promising demographic indicator of environmental behavior for the Philippines, especially when government programs (DENR, 2008), international development project (ADB, 2009) and Filipino attitudinal studies such as those on recycling (Bennagen, Nepomuceno, \& Covar, 2002), wildlife conservation (Harder, Labao, \& Santos, 2006) and economic valuation on environmental resources (Martinez \& Prantilla, 2007) routinely propose initiatives to improve environmental education.

Moreover, the results of the analysis do not seem to fully agree with the findings of previous research done by Sabio (2012) specifically on the Philippines using ISSP data. Living in rural areas only had a significant relationship to driving less and joining groups with environmental causes. For the respondent's subjective self-assessment of socioeconomic class, though a positive relationship was found for SWS classes and membership to groups, surprising negative significant relationships were found with signing petition and money with some stark contrasts between the poorest class that may imply poorer people tend to sign more petitions and being more generous in giving money to environmental causes as compared to the more self-perceiving affluent people. As such, the findings of this study suggests that the differentiating demographic factors proposed by Sabio to identify the "ecologically concerned public" (pp. 4-9) may not actually be the most significant and reliable indicators. Furthermore, as separate regression models using household income instead of SWS classes also did not provide significant results in both private and public behaviors, this underscores the necessity to shift focus from perceived economic or actual income variables towards the more consistent variable of education as an indicator of environmental concern and behaviors (Franzen \& Meyer, 2010; Franzen \& Vogl, 2013; Hadler \& Haller, 2011). 


\section{Discussion and Conclusions}

Environmental attitudes in the Philippines were found to be comprised of negative statements that express both anthropocentric and ecocentric perspectives, this can be interpreted as a reflection of Philippine environmentalism at the individual level. These attitudes were perhaps tempered by decades and generations of environmentalists conveying environmental problems as being integrated within issues of equity, livelihood, and fighting oppression. Viewed within the history and context of Philippine environmentalism, considering the compounded physical realities of natural disasters such as typhoons, droughts, and floodings that claim lives, destroys livelihoods and displaces people, together with manmade problems that cause socio-economic inequities wrought by self-serving or ineffectual institutions that stymied their welfare (Bankoff, 2004; Gaillard et al., 2005), it is understandable why Filipinos developed hardened, fatalistic, and pessimistic attitudes towards their relationship with the environment.

These can be further inferred from the results of this study with the consistently significant predictors of the Filipino attitudes being perceptions of 'the dangers of specific environmental problems' and fatalism. These results partly answer the question raised by Aoyagi et al. pertaining to their Manila sample, as to whether there 'might not yet be distinct environmental awareness or clear recognition of an association between progress and environmental destruction' (2003, p. 28-29). This relationship may also shed light as to why demographic variables and even education could not be collectively related to attitudes in a consistent significant manner, as Filipino environmentalists had 'emphasized on community action and with it being firmly rooted in specific topography'(Magno, 1993, p.17) addressing particular needs, specific dangers, and environmental problems.

The results show that no significant increases can be found in the prevalence of both public and private behaviors. This becomes interesting as the country has supposedly improved environmental conditions in air and water quality, increased institutional capacities, better social and economic indicators (ADB, 2009, pp. 3-10; DENR, 2008), together with environmentalism in the country supposedly becoming more dynamic and multi-faceted for the past two decades (Kong 2000; Magno 1993). However, if the context that environmentalists had framed and pursued is the constant struggle against oppressive forces, would the Filipinos who now live in the more progressive and developed areas paradoxically diminish in environmental concern? Conversely, for those living in areas still plagued with environmental problems, can these Filipinos eventually suffer a sort of "ecological fatigue" that would manifest in fatalistic or apathetic tendencies, if changes would not be perceived as possible or effective? Would these then entail changes on how environmentalism in the country should be promoted?

Better predictive models in the future may become possible when accounting for the local settings of respondents, especially for private behaviors that are more strongly influenced by the national context, as significant effects were found in previous studies with national affluence, political opportunity structures, and global ties on both public and private environmental behaviors (Hadler \& Haller, 2011, p.326-331). As Guagnano et al. (1995) suggests based on their study on curbside recycling, 'attitude theory needs to be modified to include both the perception of external conditions and external conditions themselves', to analytically and practically assess their effects on behavioral changes (pp. 713716).

Notwithstanding, the Negativity attitudes in the Philippines seemed to only be significant in group membership (negatively) and protest (positively); which may be considered as an extension of fatalistic or bandwagon tendencies for joining groups when hopes are high, and outward manifestation of frustration when participating in public protests. These complex relationships may also be related to tendencies among South East Asian countries observed by Kong et al. (2000) that people holding a particular attitude or belief does not necessarily amount to them acting in a consistent manner (p.133).

Perhaps, future research may even be more successful when considering other forms of environmental behavior that specifically relate to conservation, biodiversity, and other ecological concerns. The ISSP in 2010 has for instance introduced new environmental behavior variables that measure consumer preferences and may be able to show explicit concern on pertinent issues such as animal rights and natural resources conservation. Furthermore, future surveys should also explore the possibility of conducting country-specific context variables in future surveys such as specific environmental knowledge, exposure and forms of participation to ENGOs, perceptions on political opportunity structures and vulnerability to natural disasters. As Aoyagi-Usui (1999) and Reyes (2013) have pointed out, certain peoples may exhibit environmental attitudes that favor more traditional or local forms of environmentalism, and together with available resources and local contexts may engage in indigenous and ecologically low-impact practices that are not measured in current surveys that contain more mainstream and western-oriented behaviors.

In addition to looking at the traditional ways, there is also value in exploring new forms of environmentally 
significant behaviors such as online activism, forwarding SMS and E-mail, Tweeting, Facebook liking, Selfies, hashtags, posting in forums, crowdsourcing, writing congress, and other forms of electronic campaigning that 'raise awareness or at least voice concern' (Thaler, Zelnio, Freitag, MacPherson, Shiffman, Bik, Goldstein, \& McClain, 2012) may open up new opportunities for environmentalism, particularly as engagement in the more traditional notions of public behaviors were found to be decreasing over time in many countries (Hadler \& Haller, 2013), whilst private environmental behaviors had been found to be increasing - implying a shift to patterns of engagement that is more self-selected, concrete, and timelimited (p.488). Such private, convenient, and limited participation can eventually morph into newer and creative forms of activism enabled by information and communication technologies within social media platforms.

For policy makers, ENGOs, and stakeholders, the low cost of utilizing online facilities makes it affordable to expand their reach, and most social media platforms are constructed with ease of use at the forefront of their design. Social media can be one the most versatile tools in an environmentalist's arsenal when used correctly and in conjunction with a well nurtured network providing enormous return for low overhead (Thaler et al., 2012) and at the same time target the more educated sectors of the country which are also the most likely to engage in environmentally significant behavior: Especially for behaviors such as driving less, signing petitions, donating money, joining environmental causes, and participating in public protests that can be accomplished by individuals requiring very little necessary infrastructure and governmental interventions. Information and communication technology also allow those in government to know in real time and immediately assess the sentiments of online environmentalists and influence on their constituents towards particular environmental issues and concerns, in order to adjust platforms and policies accordingly.

As education is a consistent predictor of environmental behavior, aside from increasing literacy and general education standards, improvement to the prevalence of environmentally significant behavior may be achieved through augmentation of environmental education in the curriculum of the primary and secondary levels; while for the postsecondary levels, it would be worthwhile to explore and develop facilities that harness ecological predisposition such as the EENP's "Dark Green School" among others. It is also crucial to cultivate the knowledge and technical proficiency of the educated environmentalists rather than solely focusing on their economic status or capabilities: in order for future and other potential environmentalists to participate more meaningfully, and for future studies to become more substantial in the understanding of contemporary environmentalism especially in developing countries.

\section{References}

Aoyagi-Usui, M. (1999). A Comparative Analysis of Citizens' Values and Pro-Environmental Behavior. Asian Geographer, 18(1-2), 123134.

Aoyagi-Usui, M., Vinken, H., \& Kuribayashi, A. (2003). Pro-environmental Attitudes and Behaviors: An International Comparison. Human Ecology Review, 10(1), 23-31.

Asian Development Bank Report (ADB). 2009. 5th Country Environmental Analysis: Philippines 2008. ADB: Manila. Retrieved from: http://www.adb.org/sites/default/files/pub/2009/5th-Country-Environmental-Analysis-PHI.pdf

Bankoff, G. (2004). In the eye of the storm: the social construction of the forces of nature and the climatic and seismic construction of God in the Philippines. Journal of Southeast Asian Studies, 35(1), 91-112.

Bennagen, M. E., Nepomuceno, G., \& Covar, R. (2002). Solid Waste Segregation and Recycling In Metro Manila: Household Attitudes and Behavior. Economy and Environment Program for Southeast Asia.

Carriere, E., \& Scruggs, L. (2001, August). A cross-national study of the cultural sources of environmental attitudes: Evidence from the 2000 ISSP. Paper presented at the 2001 American Political Science Association Annual Meeting, San Francisco, USA.

Comrey, A., \& Lee, H. (1992). A first course in factor analysis (2nd ed.). Hillsdale, NJ: Lawrence Erlbaum.

Corral-Verdugo, V., Carrus, G., Bonnes, M., Moser, G., \& Sinha, J. B. P. (2008). Environmental Beliefs and Endorsement of Sustainable Development Principles in Water Conservation: Toward a New Human Interdependence Paradigm Scale. Environment and Behavior, 40(5), 703-725.

Del Mundo, D. M. N., Rebancos, C. M., \& Alaira, S. A. (2010). Correlation of Socio-Economic Status, Environmental Awareness, Knowledge, and Perception on Solid Waste Management Practices in Barangays Talisay and Balibago, Calatagan, Batangas, Philippines. Journal of Environmental Science and Management, 12(2), 27-37.

Department of Environment and Natural Resources (DENR), Republic of the Philippines.(2008). Compendium of Basic ENR Statistics for Operations and Management (2000-2008) (2nd ed.). Quezon City: DENR.

Didham, R. J., \& Ofei-Manu, P. (2012). Education for Sustainable Development Country Status Reports: An evaluation of national implementation during the UN Decade of Education for Sustainable Development in East and Southeast Asia. UNU-IAS/IGES Research Project on Monitoring and Evaluation of ESD. Hayama: IGES.

Dunlap, R. E., \& Van Liere, K. D. (1978). A proposed measuring instrument and preliminary results: The 'New Environmental Paradigm'. Journal of Environmental Education, 9(1), 10-19.

Field, A. (2009). Discovering statistics using SPSS. Sage publications. 
Franzen, A., \& Meyer, R. (2010). Environmental Attitudes in Cross-National Perspective: A Multilevel Analysis of the ISSP 1993 and 2000. European Sociological Review, 26(2), 219-234.

Franzen, A., \& Vogl, D. (2013). Two decades of measuring environmental attitudes: A comparative analysis of 33 countries. Global Environmental Change, 23(5), 1001-1008.

Gaillard, J. C., Liamzon, C. C., \& Maceda, E. A. (2005). Act of nature or act of man? Tracking the root causes of increasing disasters in the Philippines. Philippine Geographical Journal, 49(1-4), 45-66.

Galang, A. P. (2010). Environmental education for sustainability in higher education institutions in the Philippines. International Journal of Sustainability in Higher Education, 11(2), 173-183.

Guagnano, G. A., Stern, P. C., \& Dietz, T. (1995). Influences on attitude-behavior relationships a natural experiment with curbside recycling. Environment and behavior, 27(5), 699-718.

Hadler, M., \& Haller, M. (2011). Global activism and nationally driven recycling: The influence of world society and national contexts on public and private environmental behavior. International Sociology, 26(3), 315-345.

Hadler, M., \& Haller, M. (2013). A shift from public to private environmental behavior: Findings from Hadler and Haller (2011) revisited and extended. International Sociology, 28(4), 484-489.

Harder, D. S., Labao, R., \& Santos, F. I. (2006). Saving the Philippine Eagle: How Much would It Cost and are Filipinos Willing to Pay for It?. Willingness to Pay for the Conservation of Endangered Species In Four Asian Countries, 77. International Development Research Centre (IDRC), Singapore.

Hayes, B. C., \& Tariq, V. N. (2000). Gender differences in scientific knowledge and attitudes toward science: a comparative study of four Anglo-American nations. Public Understanding of Science, 9(4), 433-447.

Hunter, L. M., Hatch, A., \& Johnson, A. (2004). Cross-National Gender Variation in Environmental Behaviors*. Social Science Quarterly, 85(3), 677-694.

Kelly, M., Kennedy, F., Faughnan, P., \& Tovey, H. (2003). Cultural Sources of Support on which Environmental Attitudes and Behaviours Draw. September. Dublin: Environmental Protection Agency.

Kong, L., Poh Ai, I., Gusti Tisna, P., Remorin, P., Suwannatachote, R., \& Lee, W. (2000). In Yencken, D., Fien, J., \& Sykes, H., (Eds.). Environment, education and society in the Asia-Pacific: Local traditions and global discourses (pp. 113-134). London: Routledge.

Magno, F. (1993). The Growth of Philippine Environmentalism. Kasarinlan: Philippine Journal of Third World Studies, 9(1), 7-18.

Marquart-Pyatt, S. T. (2012). Contextual influences on environmental concerns cross-nationally: A multilevel investigation. Social science research, 41(5), 1085-1099.

Martinez, C. P., \& Prantilla, E. B. (2007, October ). Economic Valuation of the Groundwater in Dumoy Aquifer. Paper presented at the 10th National Convention on Statistics (NCS), Makati.

Motherway, B., Kelly, M., Faughnan, P., \& Tovey, H. (2006). Trends in Irish Environmental Attitudes between 1993 and 2002. First report from the Research Programme on Environmental Attitudes, Values and Behaviour in Ireland. Department of Sociology, University College Dublin.

Pirages, D., \& Ehrlich, P. R. (1974). Ark Il: Social response to environmental imperatives. San Francisco: WH Freeman.

Rauwald, K. S., \& Moore, C. F. (2002). Environmental Attitudes as Predictors of Policy Support across Three Countries. Environment and Behavior, 34(6), 709-739.

Reyes, J. A. L. (2013). Cross-section analyses of attitudes towards science and nature from the International Social Survey Programme 1993, 2000, and 2010 surveys. Public Understanding of Science, doi: 10.1177/0963662513503261

Robinson, J. P., Shaver, P. R., \& Wrightsman, L. S. (1991). Criteria for scale selection and evaluation. Measures of personality and social psychological attitudes, 1(3), 1-16.

Sabio, G. S. S. (2012,June). Are We A Greener Nation Now? Trends in Pro-Environmental Behaviors of Filipinos (1993-2010). Paper presented at the 65th Annual WAPOR Conference in Hong Kong. World Association for Public Opinion Research, China http://wapor2012. hkpop.hk/doc/papers/ConcurrentSessionsV/VC/VC-3.pdf.

Tabachnick, B. G. \& Fidell, L. S., (2006). Using multivariate statistics. Boston: Allyn \& Bacon.

Thaler, A., Zelnio, K., Freitag, A., MacPherson, R., Shiffman, D., Bik, H., Goldstein, M., \& McClain, C. (2012). Digital environmentalism: Tools and strategies for the evolving online ecosystem. In Deborah Rigling Gallagher (Ed.), Environmental leadership: $A$ reference handbook. (pp. 364-373). Thousand Oaks, CA: SAGE Publications.

Van Petegem, P., \& Blieck, A. (2006). The environmental worldview of children: a cross-cultural perspective. Environmental Education Research, 12(5), 625-635. 


\section{Appendix}

Table A1: Survey Characteristics

\begin{tabular}{|c|c|c|c|c|c|c|}
\hline & $\begin{array}{c}\text { ISSP } \\
1993 \\
\end{array}$ & & $\begin{array}{l}\text { ISSP } \\
2000 \\
\end{array}$ & & $\begin{array}{l}\text { ISSP } \\
2010 \\
\end{array}$ & \\
\hline & Valid N & $\%$ & Valid N & $\%$ & Valid N & $\%$ \\
\hline Philippine Sample & 1200 & & 1200 & & 1200 & \\
\hline Gender & & & & & & \\
\hline Male & 600 & $50.0 \%$ & 600 & $50.0 \%$ & 600 & $50.0 \%$ \\
\hline Female & 600 & $50.0 \%$ & 600 & $50.0 \%$ & 600 & $50.0 \%$ \\
\hline \multicolumn{7}{|l|}{ Respondent's Educational Level } \\
\hline Pre-Secondary & 344 & $29.1 \%$ & 338 & $28.5 \%$ & 170 & $17.1 \%$ \\
\hline Secondary & 420 & $35.5 \%$ & 479 & $40.4 \%$ & 454 & $45.5 \%$ \\
\hline Post-Secondary & 420 & $35.5 \%$ & 370 & $31.2 \%$ & 373 & $37.4 \%$ \\
\hline \multicolumn{7}{|c|}{ SWS Socio-Economic Class (R's subjective self-placement) } \\
\hline ABC (Middle to Upper classes) & 239 & $19.9 \%$ & 445 & $39.1 \%$ & 373 & $31.2 \%$ \\
\hline D (Lower Middle class) & 825 & $68.8 \%$ & 104 & $9.1 \%$ & 423 & $35.4 \%$ \\
\hline E (Working class) & 104 & $8.7 \%$ & 185 & $16.3 \%$ & 291 & $24.3 \%$ \\
\hline $\mathrm{F}$ (Lower class) & 32 & $2.7 \%$ & 404 & $35.5 \%$ & 109 & $9.1 \%$ \\
\hline \multicolumn{7}{|l|}{ Place of Living } \\
\hline Urban & 750 & $62.5 \%$ & 595 & $49.6 \%$ & 623 & $52.5 \%$ \\
\hline Rural & 450 & $37.5 \%$ & 605 & $50.4 \%$ & 563 & $47.5 \%$ \\
\hline
\end{tabular}

Table A2: Variable descriptions (Items in Tagalog for Philippine survey)

\section{Attitudes to Science and Nature}

(Bracketed items indicate DSP or NEP categorization based on Aoyagi-Usui (1993) and Reyes (2013)

How much do you agree or disagree with each of these statements? Do you Strongly Agree, Agree, Neither Agree nor Disagree, Disagree, Strongly Disagree, or Can't Choose?

(Gaano kayo sumasang-ayon o hindi sumasang-ayon sa mga pangungusap na ito? Masasabi ba ninyo na kayo ay Talagang Sumasangayon, Sumasang-ayon, Maaaring Sumasang-ayon/Maaaring Hindi, Hindi Sumasang-ayon, Talagang Hindi Sumasang-ayon, o Hindi Makapili?)

1. We believe too often in science, and not enough in feelings and faith [NEP]

(Mas madalas tayo ay naniniwala agad sa siyensya/agham at kulang sa damdamin at pananampalataya)

2. Overall, modern science does more harm than good [NEP]

(Sa pangkalahatan, ang makabagong siyensya/agham ay nagdudulot ng mas maraming kapinsalaan kaysa kabutihan)

3. Modern science will solve our environmental problems with little change to our way of life [DSP]

(Malulutas ng makabagong siyensya/agham ang mga problema natin sa kapaligiran na kaunti lamang ang mababago sa paraan ng ating pamumuhay)

4. We worry too much about the future of the environment and not enough about prices and jobs today [DSP]

(Masyado tayong nag-aalala tungkol sa kinabukasan ng kapaligiran at walang sapat na pag-aalala sa kasalukuyang presyo ng mga bilihin at trabaho)

5. Almost everything we do in modern life harms the environment [NEP]

(Lahat halos ng ginagawa natin sa makabagong pamumuhay ay nakasasama sa kapaligiran)

6. People worry too much about human progress harming the environment [DSP] 
(Masyadong nag-aalala ang mga tao na sa kabila ng sangkatauhang pag-unlad, nasisira naman ang kapaligiran)

7. In order to protect the environment, the Philippines needs economic growth [DSP]

(Upang mapangalagaan ang kapaligiran, kinakailangan ng pilipinas na paunlarin ang ekonomiya)

8. Economic growth always harms the environment [NEP]

(Ang pag-unlad ng ekonomiya ay laging nakapipinsala sa kapaligiran)

\section{Willingness to Make Trade-Offs for the Environment}

Very willing (Payag na payag), Fairly willing (Medyo payag), Neither willing nor unwilling (Maaaring payag/maaaring hindi), Fairly unwilling (Medyo hindi payag), Very unwilling (Hinding-hindi papayag), Can't choose (Hindi makapili)

1. How willing would you be to pay much higher prices in order to protect the environment?

(Gaano kayo pumapayag na magbayad ng mas mataas na presyo upang mapangalagaan ang kapaligiran?) [Prices]

2. How willing would you be to pay much higher taxes in order to protect the environment?

(Gaano kayo pumapayag na magbayad ng mas mataas na buwis upang mapangalagaan ang kapaligiran?) [Taxes]

3. How willing would you be to accept cuts in your standard of living in order to protect the environment? [Living]

(Gaano naman kayo pumapayag na tanggapin ang kaunting pagbaba sa antas ng inyong pamumuhay upang mapangalagaan ang kapaligiran?)

\section{Dangers of Specific Environmental Problems}

Extremely dangerous (Lubhang napaka-mapanganib), Very dangerous (Napaka-mapanganib), Somewhat dangerous (Medyo mapanganib), Not very dangerous (Hindi gaanong mapanganib), Not dangerous at all (Talagang hindi mapanganib), Can't choose (hindi makapili)

1. In general, do you think that air pollution caused by cars is <response > for the environment?

(Sa pangkalahatan, sa palagay ba ninyo ang polusyon sa hangin na dulot ng mga sasakyan ay <response> para sa kapaligiran?) [AirPolCarEnv]

2. In general, do you think that air pollution caused by industry is <response> for the environment?

(Sa pangkalahatan, sa palagay ba ninyo ang polusyon sa hangin na dulot ng mga industriya ay <response> para sa kapaligiran?) [AirPollndEnv]

3. And do you think that pesticides and chemicals used in farming is < response $>$ for the environment?

(At sa palagay naman ba ninyo ang mga pamatay-insekto at kemikal na ginagamit sa pagsasaka ay <response> para sa kapaligiran?)[ PestFarmEnv]

4. In general, do you think that a rise in the world's temperature caused by the 'greenhouse effect'is <response> for the environment?

(Sa pangkalahatan, sa palagay ba ninyo ang pagtaas ng temperatura ng mundo na dulot ng 'greenhouse effect' o pag-init ng mundo ay $<$ response> para sa kapaligiran?) [RiseWorldTemp]

5. And do you think that pollution of Philippine rivers, lakes and streams is <response > for the environment?

(At sa palagay ba ninyo ang polusyon sa mga ilog, lawa at batis dito sa Pilipinas ay <response> para sa kapaligiran?) [PolLakeRivEnv]

\section{Environmental Efficacy}


How much do you agree or disagree with each of these statements? Do you Strongly Agree, Agree, Neither Agree nor Disagree, Disagree, Strongly Disagree, or Can't Choose?

(Gaano kayo sumasang-ayon o hindi sumasang-ayon sa mga pangungusap na ito? Masasabi ba ninyo na kayo ay Talagang Sumasangayon, Sumasang-ayon, Maaaring Sumasang-ayon/Maaaring Hindi, Hindi Sumasang-ayon, Talagang Hindi Sumasang-ayon, o Hindi Makapili?)

1. It is just too difficult for someone like me to do much about the environment (Napakahirap para sa isang katulad ko ang makagawa ng malaking bagay tungkol sa kapaligiran) [EfficFatalism]

2. I do what is right for the environment, even when it costs more money or takes more time (Ginagawa ko ang tama para sa kapaligiran kahit na gumastos ako ng mas malaki o mag-ukol ng mas maraming panahon dito) [EfficAltruism]

Items were recoded to indicate increasing agreement/willingess/concern/ etc., i.e. 1 to indicate strong disagreement while 5 indicating strong agreement of respondents.

For postmaterialism and locus of control-state intervention items, scales were created similarly to those utilized by Hadler \& Haller (2011)

\section{Environmental Behavior and Environmental Protection}

Private

How often do you make a special effort to ...? Always, Often, Sometimes, Never, Not available where I live (Gaano kadalas ninyong sinisikap na...? Palagi, Madalas, Paminsan-minsan, Talagang hindi, Wala sa aming lugar)

1. Sort glass or tins or plastic or newspapers and so on for recycling (pagbukud-bukurin ang mga bote 0 lata 0 plastic 0 diyaryo at iba pang bagay para muling magamit ang mga ito) [Sorting]

2. And how often do you cut back on driving a car for environmental reasons (At gaano naman kadalas kayong magbawas sa pagmamaneho/paggamit ng sasakyan nang dahil sa kapaligiran) [Car]

Public

1. Are you a member of any group whose main aim is to preserve or protect the environment? (Kayo po ba ay miyembro ng anumang grupo na ang pangunahing layunin/adhikain ay ang pagpapanatili at pangangalaga ng kapaligiran) [Group] Yes, No In the last five years, have you ... (Sa nakaraang limang taon, kayo po ba ay ...)

2. Signed a petition about an environmental issue (Pumirma na sa isang petisyon tungkol sa isang isyung pangkapaligiran) [Petition]

3. Given money to an environmental group (Nagbigay na ng pera sa isang grupong pangkapaligiran) [Money]

4. Taken part in a protest or demonstration about an environmental issue (Nakilahok na sa isang protesta o demonstrasyon tungkol sa isang isyung pangkapaligiran) [Protest] 